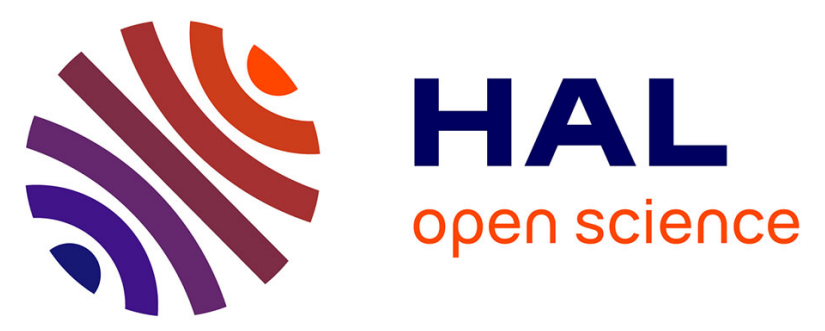

\title{
Comparing the deposition mechanisms in suspension plasma spray (SPS) and solution precursor plasma spray (SPPS) deposition of yttria-stabilised zirconia (YSZ)
} Aurélien Joulia, Giovanni Bolelli, Enrico Gualtieri, Luca Lusvarghi, Sergio Valeri, Michel Vardelle, Armelle Vardelle, S. Rossignol

\section{To cite this version:}

Aurélien Joulia, Giovanni Bolelli, Enrico Gualtieri, Luca Lusvarghi, Sergio Valeri, et al.. Comparing the deposition mechanisms in suspension plasma spray (SPS) and solution precursor plasma spray (SPPS) deposition of yttria-stabilised zirconia (YSZ). Journal of the European Ceramic Society, 2014, 11 p. 10.1016/j.jeurceramsoc.2014.05.024 . hal-01016476

\author{
HAL Id: hal-01016476 \\ https://hal.science/hal-01016476
}

Submitted on 11 Jul 2014

HAL is a multi-disciplinary open access archive for the deposit and dissemination of scientific research documents, whether they are published or not. The documents may come from teaching and research institutions in France or abroad, or from public or private research centers.
L'archive ouverte pluridisciplinaire HAL, est destinée au dépôt et à la diffusion de documents scientifiques de niveau recherche, publiés ou non, émanant des établissements d'enseignement et de recherche français ou étrangers, des laboratoires publics ou privés. 


\title{
THE ROLE OF HEMATITE IN ALUMINOSILICATE GELS BASED ON METAKAOLIN
}

\author{
N. ESSAIDI*,**, B. SAMET*, S. BAKLOUTI*, ${ }^{\#}$ S. ROSSIGNOL** \\ *Laboratoire de Chimie Industrielle, Ecole Nationale d'Ingénieurs de Sfax, BP W 3038, Sfax, Tunisia \\ **Centre Européen de la Céramique, Groupe d'Etude des Matériaux Hétérogènes, \\ Ecole Nationale Supérieure de Céramique Industrielle, 12 rue Atlantis 87068 Limoges, France \\ "E-mail: sylvie.rossignol@unilim.fr
}

Submitted July 24, 2013; accepted November 26, 2013

\begin{abstract}
Keywords: Hematite, Kaolin, Polycondensation reaction, Natural clay, Infrared spectroscopy
This paper investigates the role of iron oxide in natural clay and its contribution to polycondensation reactions. Iron oxide was added to pure kaolin in the same proportion as Medenine clay with different amounts of potassium hydroxide. The physicochemical and structural properties of these materials were determined by infrared spectroscopy, scanning electron microscopy, thermal analyses (DTA-TG) and X-ray diffraction. The amorphous character seen in the diffractograms obtained from the materials and the displacement of the IR wavenumber are indicative of a polycondensation reaction.

The representative characterization of the microstructure of different samples using electron microscopy highlights the nonreactivity of iron exhibited during consolidation. In general, the contribution of iron oxide seems to be small under the conditions described here.
\end{abstract}

\section{INTRODUCTION}

Tunisia is among the countries that have significant deposits and quantities of clay as a part of its geology. However, research on the development of this resource is limited. Few authors (A. Chakchouk et al., 2006) [1] have tested Tunisian clay that has been calcined at different temperatures for use as pozzolanic materials. Other studies have been conducted on the use of Tunisian clays in ceramics [2], despite containing minerals such as iron oxide, as is the case for Medenine clay. Recently, these natural clays have been proposed as raw materials for the synthesis of a new class of building materials called geopolymers [3]. The production of these geopolymeric materials provides an obvious economic and environmental advantage via a reduction in energy consumption and in $80 \%$ of $\mathrm{CO}_{2}$ emissions.

Geopolymers are dense "gels" of amorphous silicoaluminates, obtained by mixing an alkaline silicate solution and an aluminosilicate source, such as metakaolin or fly ash. Because geopolymers possess attractive material properties, they are presently used in several applications, such as thermal insulation, refractory materials, and anti-corrosion coatings; however, their main use today is in construction. Among the different families of geopolymers, there are some that contain iron oxide (hematite) added in small quantities [4] (without the presence of aluminum). The resultant material is insoluble in water. X-ray analysis of these materials show a broad amorphous peak centered near $25-20^{\circ}$ that is indicative of short range ordering. The material formed is composed of a tetrahedral network occupied by silicates or iron in a primarily octahedral orientation. The addition of iron to a metakaolin based geopolymer was studied in detail by DS Perera et al. [5]. The basic approach was to introduce ferric iron, either as a soluble salt or as an (oxy) hydroxide precipitate. In this study, metakaolin was mixed in a solution of sodium silicate, and iron was added later as a minority phase. Under these conditions, the rapid formation of the aluminosilicate does not leave enough time for the iron to participate in the geopolymerization reaction. From X-ray diffraction and electron microscopy, it was concluded that in as-cured geopolymers the $\mathrm{Fe}$ was present in octahedral sites, either as isolated ions in the geopolymer matrix or as oxyhydroxide aggregates which had not reacted with the starting geopolymer components. According to these authors, iron can be a major component of mining wastes and it can exist in many forms, but it would be more likely to affect the kinetics and overall chemistry of geopolymer formation if the iron was relatively soluble form. Choi et al. [6] discussed the effect of the addition of $\mathrm{Fe}_{2} \mathrm{O}_{3}$ on the physical properties of geopolymeric materials based on raw materials containing $\mathrm{CaO}$. They showed a difference of compressive strength caused by $\mathrm{Fe}$ inhibition to geopolymerization reaction and form of C-S-H gel. 
Others works [7] have studied the solubility of hematite in alkaline solutions and proven that the solubility increases with temperature and the concentration of the alkali metal hydroxide, even though the solubility is still considered very low. The solubility of hematite changes significantly, depending on the nature of the alkali metal hydroxide $(\mathrm{KOH}<\mathrm{NaOH})$. It has been shown [8] that the dissolved silicates can adsorb onto the surface of various iron oxides with different affinities, such as hematite $\left(\mathrm{Fe}_{2} \mathrm{O}_{3}\right)$. Additionally, the adsorption of dissolved silicates on iron oxides occurs over a wide $\mathrm{pH}$ range [8-10]. A thermal analysis of clay containing iron oxide shows fewer mass losses than clay not containing iron oxide or experiencing dehydration phenomena, dehydroxylation and recrystallization $[9,10]$. However, the shift in the observed peak is attributed to the structural reorganization of metakaolinite at low temperatures for samples containing iron. [11] In conclusion, the presence of iron oxide does not inhibit the formation of a geopolymer, but it does influence the characteristics of the obtained material.

The aim of this work is to understand the role of iron oxide in the geopolymerization reaction of natural clay. In this approach, a geopolymer mixture is synthesized with the same composition as clay. To accomplish this, kaolin or metakaolin are mixed with iron oxide and different amounts of $\mathrm{KOH}$. These various materials are characterized in-situ or after consolidation using different methods.

\section{EXPERIMENTAL}

\section{Raw minerals and consolidated} materials

The reference clay in this study is a Tunisian clay from the south of Medenine. It is characterized by its composition $\left(\mathrm{SiO}_{2}=67.5 \%, \mathrm{Al}_{2} \mathrm{O}_{3}=18 \%\right)$ [12].

The consolidated materials were prepared from a solution containing kaolinite supplied by IMERYS, iron oxide $\left(\mathrm{Fe}_{2} \mathrm{O}_{3}\right.$, particle size $<5 \mu \mathrm{m}, 99 \%$ purity $)$ and $\mathrm{KOH}$ pellets ( $85.7 \%$ purity) dissolved in potassium silicate, as described in Figure 1. Two different methods were used to synthesize the consolidated materials from a mixture of either $\left(\mathrm{kaolin} / \mathrm{Fe}_{2} \mathrm{O}_{3}\right.$ ) or (metakaolin $/ \mathrm{Fe}_{2} \mathrm{O}_{3}$ ).

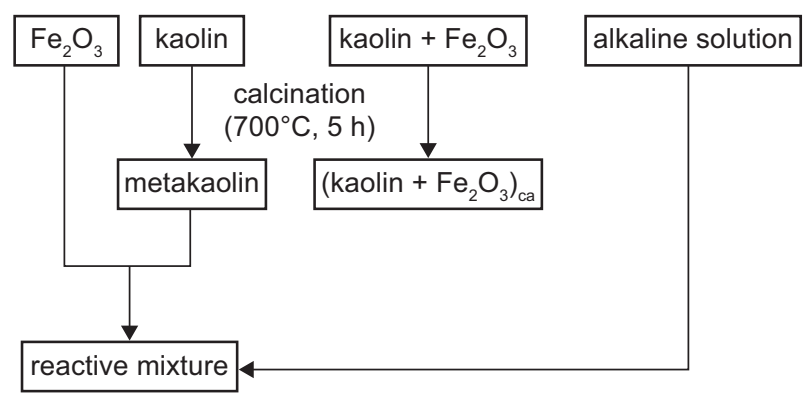

Figure 1. Synthesis protocol of consolidated materials.
The materials were prepared by first dissolving potassium hydroxide in potassium silicate and then adding the clay/hematite mixture to the alkaline solution and mixing until the resulting paste was homogenous, according to the procedure established by Prud'homme et al. in 2010 [13].

After mixing, the paste specimens were poured into plastic containers $(\varnothing=15 \mathrm{~mm}, H=35 \mathrm{~mm})$ and cured at $70^{\circ} \mathrm{C}$ for 24 hours, followed by 7 days at ambient temperature.

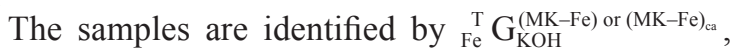
where $\mathrm{Fe}$ is the mass of $\mathrm{Fe}_{2} \mathrm{O}_{3}(\mathrm{~g})$, $\mathrm{T}$ is the calcination temperature and $\mathrm{KOH}$ is the mass of $\mathrm{KOH}$ contained in 1 $\mathrm{g}$ of the mixture (kaolin and $\mathrm{Fe}_{2} \mathrm{O}_{3}$ ).

The designation $\left[(\mathrm{K}-\mathrm{Fe})_{c a}\right]$ means that the raw materials are composed of a mixture of kaolin and iron oxide calcined together; whereas [MK-Fe] means that the raw materials are composed of a mixture of metakaolin and iron oxide.

As an example, the compound ${ }_{0.12 \mathrm{Fe}} \mathrm{G}_{0.18}^{(\mathrm{KFe})_{\text {ca }}}$ is obtained from a mixture of kaolin and $\mathrm{Fe}_{2} \mathrm{O}_{3}$ calcined together at $\mathrm{T}=$ $=700^{\circ} \mathrm{C}$ and contains $0.12 \mathrm{~g}$ of iron oxide and $0.18 \mathrm{~g}$ of potassium hydroxide.

\section{Technical characterization}

The mineral phases were identified by powder X-ray diffraction (XRD) with a BRUKERAXSD8 Advance powder diffractometer using $\mathrm{CuK}_{\alpha}$ radiation $\left(\lambda_{\mathrm{K} \alpha}=0.154186 \mathrm{~nm}\right)$. The analytical range used was between $5^{\circ}$ and $70^{\circ}$ with a step size of $0.04^{\circ}$ and an acquisition time of 2 s. JCPDS (Joint Committee Powder Diffraction Standard) files were used for phase identification.

The particle size distributions of these raw materials were measured using a laser particle size analyzer (Mastersizer 2000). The mixture contained $1 \mathrm{~g}$ of clay in $20 \mathrm{ml}$ of water, mixed by ultrasound to eliminate any aggregation. The dispersant used was water. The measured particle sizes are in the range $0.05-880$ microns. Additionally, the concentration of the solution should not be too large (obscuration $<35 \%$ ).

Powder BET surface areas were determined by $\mathrm{N}_{2}$ adsorption at $-195.85^{\circ} \mathrm{C}$ using a Micrometrics Tristar II 3020 volumetric adsorption/desorption apparatus. Prior to the measurement, the samples were degassed at $200^{\circ} \mathrm{C}$ under vacuum for $24 \mathrm{~h}$.

The wetability, expressed in $\mathrm{cm}^{3} / \mathrm{g}$, corresponds to the volume of water that can be absorbed by one gram of powder to saturation.

Differential thermal analyses (DTA) and thermogravimetric analyses (TG) were performed with the samples held in a Pt crucible between $25^{\circ} \mathrm{C}$ and $1200^{\circ} \mathrm{C}$ using a SDTQ600V20.9. The samples were heated at a rate of $20^{\circ} \mathrm{C} \mathrm{min}^{-1}$ in a dry air flow.

The FTIR spectra were obtained from a Thermo Fischer Scientific 380 infrared spectrometer (Nicolet) 
using the attenuated total reflection (ATR) method. A drop of the geopolymer reactant mixture was deposited on the instrument's diamond crystal and protected with a small bell from any environmental pollution during the spectrum acquisition process, which was performed regularly until the end of the geopolymerization process. The IR spectra were gathered between 500 and $4000 \mathrm{~cm}^{-1}$ at a resolution of $4 \mathrm{~cm}^{-1}$. The commercial software OMNIC (Nicolet Instruments) was used for data acquisition and spectral analysis. The spectra were recorded every $10 \mathrm{~min}$ for $13 \mathrm{~h}$ to permit the superposition of 72 raw spectra [14]. Measurements were carried out at different times.

The morphology of the final products was observed using a Philips XL 30 scanning electron microscope (SEM) at $15 \mathrm{kV}$ coupled with an EDX spectrometer. Prior to observations, a thin layer of $\mathrm{Au} / \mathrm{Pd}$ was deposited on the samples.

The shrinkage per unit volume of samples is determined using (Equation 1):

$\frac{\mathrm{Vf}}{\mathrm{Vi}}=\frac{\text { final volume of sample after } 2 \mathrm{~h} \text { its removal from the oven }}{\text { initial volume of sample }}$

where $V=(\Pi \times \Phi \times H) / 4, H$ is the height of the sample and $\Phi$ is the diameter of the sample.

\section{RESULTS}

Precursor mixtures

The properties of the geopolymer materials are strongly influenced by the raw materials used during fabrication. The various raw materials used in the preparation of the geopolymer, such as the Imerys kaolin and iron oxide, are characterized using several different methods of physicochemical analysis. Physicochemical data, such as the specific surface, $\mathrm{D}_{50}$ (particle size) and wettability of the precursors, are shown in Table 1 . The specific surface area of the powders is similar for iron oxide $\left(4 \mathrm{~m}^{2} / \mathrm{g}\right)$ and metakaolin $\left(8 \mathrm{~m}^{2} / \mathrm{g}\right)$. These values do not change significantly during alkaline attack. The data analysis shows that the iron oxide particle size has a $D_{50}$ of approximately $0.1 \mu \mathrm{m}$, which is considered small. The metakaolin $\left(\mathrm{M}_{\mathrm{I}}\right)$ has a $\mathrm{D}_{50}$ of approximately $7.5 \mu \mathrm{m}$, which is slightly greater than the $\mathrm{D}_{50}$ of kaolin $\left(\mathrm{K}_{\mathrm{I}}\right)$. The $\left(\mathrm{K}_{\mathrm{I}}+\mathrm{Fe}\right)_{\text {no ca }}\left(\mathrm{K}_{\mathrm{I}}+\mathrm{Fe}\right)_{\text {ca }}$ and $\left(\mathrm{M}_{\mathrm{I}}+\mathrm{Fe}\right) \mathrm{mix}-$ tures have $\mathrm{D}_{50}$ values of approximately 5,7 and $7 \mu \mathrm{m}$, respectively. These values demonstrate the effect of powder agglomeration during calcination.

The diffractograms of the different precursors used in this study are shown in Figure 2. The Imerys kaolin $\left(\mathrm{K}_{\mathrm{I}}\right)$ precursor has a diffractogram characteristic of a kao-

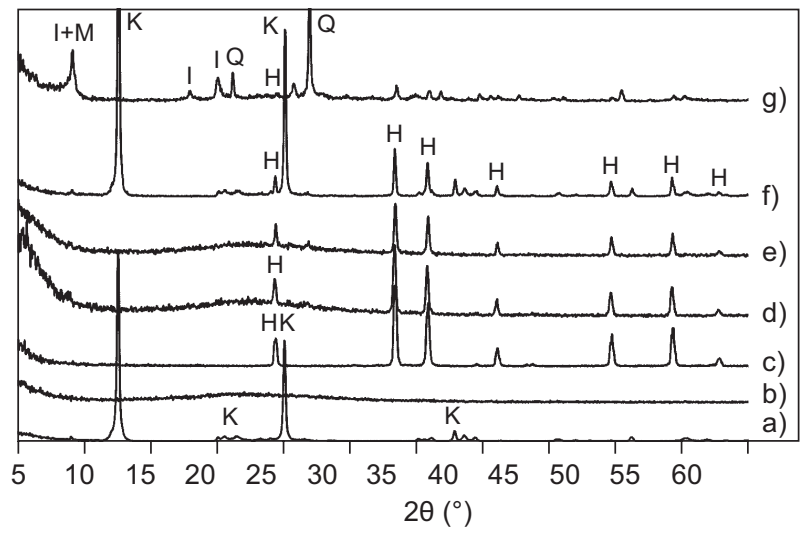

Figure 2. X-Ray patterns of a) kaolin, b) calcined kaolin, c) $\mathrm{Fe}_{2} \mathrm{O}_{3}$, d $)\left(\mathrm{K}_{\mathrm{I}}+\mathrm{Fe}\right)_{\text {ca }}$, e $\left.)\left(\mathrm{M}_{\mathrm{I}}+\mathrm{Fe}\right), \mathrm{f}\right)\left(\mathrm{K}_{\mathrm{I}}+\mathrm{Fe}\right)_{\text {no ca }}$ and g) Medenine clay calcined at $700^{\circ} \mathrm{C}$ precursors (JCPDS Files: K: kaolinite (00-003-0059), H: hematite (04-008-7624), Q: quartz (04-012-0490), I: illite (00-002-0462), M: muscovite (04-0121956).

Table 1. Various data of raw and consolidated materials.

\begin{tabular}{|c|c|c|c|c|c|c|c|}
\hline & & $\mathrm{Si} / \mathrm{K}$ & $\mathrm{Si} / \mathrm{Al}$ & $\begin{array}{l}\text { SBET } \\
\left(\mathrm{m}^{2} / \mathrm{g}\right)\end{array}$ & $\mathrm{D}_{50}$ & $\begin{array}{l}\text { Wetting } \\
\left(\mathrm{cm}^{3} / \mathrm{g}\right)\end{array}$ & $\begin{array}{c}\text { Compressive } \\
\text { strengh }(\mathrm{MPa})\end{array}$ \\
\hline \multirow{6}{*}{ 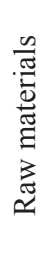 } & $\mathrm{K}_{\mathrm{I}}$ & - & 1 & 6 & 7.0 & 1.50 & - \\
\hline & $\mathrm{M}_{\mathrm{I}}$ & - & 1 & 8 & 7.5 & 1.40 & - \\
\hline & $\mathrm{Fe}_{2} \mathrm{O}_{3}$ & - & - & 4 & 0.1 & 0.96 & - \\
\hline & $\left(\mathrm{K}_{\mathrm{I}}+\mathrm{Fe}\right)_{\text {non ca }}$ & - & 1 & 6 & 5.0 & 1.15 & - \\
\hline & $\left(\mathrm{K}_{\mathrm{I}}+\mathrm{Fe}\right)_{\mathrm{ca}}$ & - & 1 & 7 & 7.0 & 1.25 & - \\
\hline & $\left(\mathrm{M}_{\mathrm{I}}+\mathrm{Fe}\right)$ & - & - & 7 & 7.0 & 1.18 & - \\
\hline \multirow{8}{*}{ 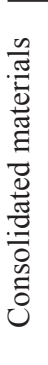 } & ${ }_{0.12 \mathrm{Fe}}^{700} \mathrm{G}_{0.18}^{\mathrm{M}_{1}-\mathrm{Fe}}$ & 2.28 & 1.17 & - & - & - & 1.0 \\
\hline & $\begin{array}{l}700 \\
0.12 \mathrm{Fe} \\
\mathrm{G}_{0.38} \mathrm{M}_{1}-\mathrm{Fe}\end{array}$ & 1.39 & 1.17 & - & - & - & 3.0 \\
\hline & ${ }_{0.12 \mathrm{Fe}}^{700} \mathrm{G}_{0.18}^{\left(\mathrm{K}_{1}-\mathrm{Fe}\right)_{\mathrm{ca}}}$ & 2.28 & 1.17 & - & - & - & 1.0 \\
\hline & ${ }_{0.12 \mathrm{Fe}}^{700} \mathrm{G}_{0.38}^{\left(\mathrm{K}_{1}-\mathrm{Fe}\right)_{\mathrm{ca}}}$ & 1.39 & 1.17 & - & - & - & 2.0 \\
\hline & ${ }_{0 \mathrm{Fe}}^{700} \mathrm{G}_{0.18}^{\mathrm{M}_{\mathrm{I}}}$ & 2.55 & 1.15 & - & - & - & 1.0 \\
\hline & ${ }_{0 \mathrm{Fe}} \mathrm{G}_{0.38}^{\mathrm{M}_{1}}$ & 1.56 & 1.15 & - & - & - & 3.0 \\
\hline & ${ }_{0 \mathrm{Fe}}^{25} \mathrm{G}_{0.18}^{\mathrm{K}_{1}}$ & 2.24 & 1.18 & - & - & - & 1.0 \\
\hline & ${ }_{0 \mathrm{Fe}}^{25} \mathrm{G}_{0.38}^{\mathrm{K}_{1}}$ & 1.38 & 1.18 & - & - & - & 2.0 \\
\hline
\end{tabular}


linitic phase without impurities. Calcination at $700^{\circ} \mathrm{C}$ leads to the dehydroxylation of the kaolinite, which is characterized by the amorphous nature of the metakaolin compound $\left(\mathrm{M}_{\mathrm{I}}\right)$.

The diffractogram of the $\left(\mathrm{K}_{\mathrm{I}}+\mathrm{Fe}\right)_{\text {no ca }}$ mixture indicates the presence of kaolinite and iron oxide peaks. The diffractograms of the $\left(\mathrm{K}_{\mathrm{I}}+\mathrm{Fe}\right)_{\mathrm{ca}}$ and $\left(\mathrm{M}_{\mathrm{I}}+\mathrm{Fe}\right)$ mixtures show a disappearance of the kaolinite phase and the persistence of hematite after calcinations is completed. Therefore, the diffractograms of the $\left(\mathrm{K}_{\mathrm{I}}+\mathrm{Fe}\right)_{\mathrm{ca}}$ and $\left(\mathrm{M}_{\mathrm{I}}+\mathrm{Fe}\right)$ mixtures are similar to the original product due to the presence of the iron oxide peaks $\left(\mathrm{Fe}_{2} \mathrm{O}_{3}\right)$ (hematite). Mixing iron oxide into metakaolin or calcining the $\left(\mathrm{K}_{\mathrm{I}}+\mathrm{Fe}\right)$ mixture provides no substantial structural modification. This result is likely explained by no interaction taking place between the clay phases and the iron oxide at this temperature [15]. In comparison, the diffractogram of the Medenine clay (Figure 2g) is characterized by the presence of impurities (illite, quartz), unlike the precursors, which are based on kaolin and hematite. For the calcined samples, the presence of hematite and an amorphous clay phase may be favorable for the formation of geopolymerization reactions.

The thermograms of the $\mathrm{K}_{\mathrm{I}}\left(\mathrm{K}_{\mathrm{I}}+\mathrm{Fe}\right)_{\mathrm{ca}}$ and $\left(\mathrm{K}_{\mathrm{I}}+\mathrm{Fe}\right)$ no ca samples are shown in Figure 3. An analysis of the sample $\mathrm{K}_{\mathrm{I}}$ thermogram (Figure $3 \mathrm{a}$ ) reveals the presence of two endothermic peaks located at $120^{\circ} \mathrm{C}$ and $400^{\circ} \mathrm{C}$, respectively. The first peak corresponds to the loss of the physisorbed water molecules, and the second is related to the loss of the structural water. The exothermic peak at $984^{\circ} \mathrm{C}$ may be attributed to the nucleation of mullite [16]. The mass losses associated with these peaks agree within $1 \%$ and $14 \%$ of the pure kaolin peaks. An analysis of the $\left(\mathrm{K}_{\mathrm{I}}+\mathrm{Fe}\right)_{\text {no ca }}$ (Figure $3 \mathrm{~b}$ ) mixture reveals the presence of the same endothermic and exothermic phenomena, namely dehydration, dehydroxylation and recrystallization. The mass loss from the $\left(\mathrm{K}_{\mathrm{I}}+\mathrm{Fe}\right)_{\text {no ca }}$ mixture is calculated to be approximately $10 \%$. This loss, compared to the kaolin $(14 \%)$, is consistent with the addition of $5 \%$ iron oxide. The thermogram of the $\left(\mathrm{K}_{\mathrm{I}}+\mathrm{Fe}\right)_{\mathrm{ca}}$ mixture (Figure $3 \mathrm{c}$ ) shows only the presence of a very low endothermic peak assigned to dehydration and an exothermic peak related to recrystallization.

The SEM pictures of the different precursors are shown in Figure 4. The characteristics of the hematite particles are $<1$ micron in size, which agrees with the value for $\mathrm{D}_{50}$, which is very low (approximately $0.1 \mu \mathrm{m}$ ). Furthermore, these particles and the agglomerated hexagonal shape have a specific surface area of approximately $4 \mathrm{~m}^{2} / \mathrm{g}$ (Table 1 ), which is consistent with this morphology [17]. The $\left(\mathrm{K}_{\mathrm{I}}+\mathrm{Fe}\right)_{\text {no ca }}$ mixture reveals the presence of layers of kaolinite and hematite particles. After calcination, the mixture is characterized by the presence of hematite particles and non-dehydroxylated sheets characteristic of kaolinite and metakaolin particles. Autef et al. [18] observed the presence of partially dehydroxylated kaolin platelets. Both photos of the
$\left(\mathrm{M}_{\mathrm{I}}+\mathrm{Fe}\right)$ and $\left(\mathrm{K}_{\mathrm{I}}+\mathrm{Fe}\right)_{\text {ca }}$ SEM samples may be obtained in-situ or ex-situ because both mixtures have the same morphologies. This result is explained by the nonreactivity exhibited between the iron oxide and the clay material when treated at $700^{\circ} \mathrm{C}$, as mentioned above.

These data show that the addition of $5 \% \mathrm{Fe}_{2} \mathrm{O}_{3}$ does not affect the behavior of kaolin at this temperature, and therefore, there is no interaction between the $\mathrm{Fe}_{2} \mathrm{O}_{3}$ and kaolin. This finding agrees with the literature [19], which shows that these compounds are stable in the temperature range considered here.

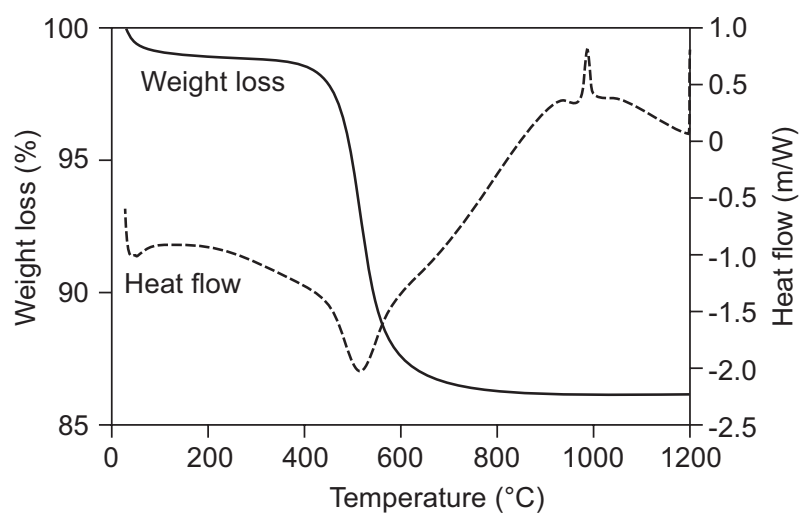

a) $\mathrm{K}_{\mathrm{I}}$

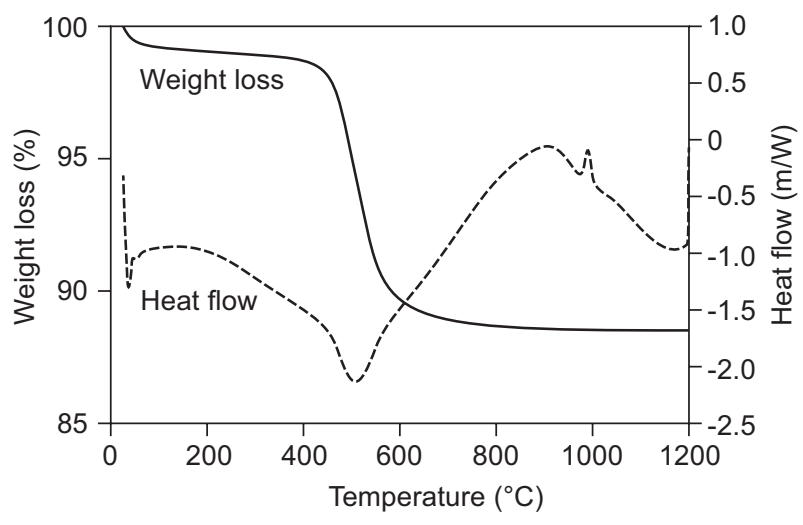

b) $\left(\mathrm{K}_{\mathrm{I}}+\mathrm{Fe}\right)_{\text {no ca }}$

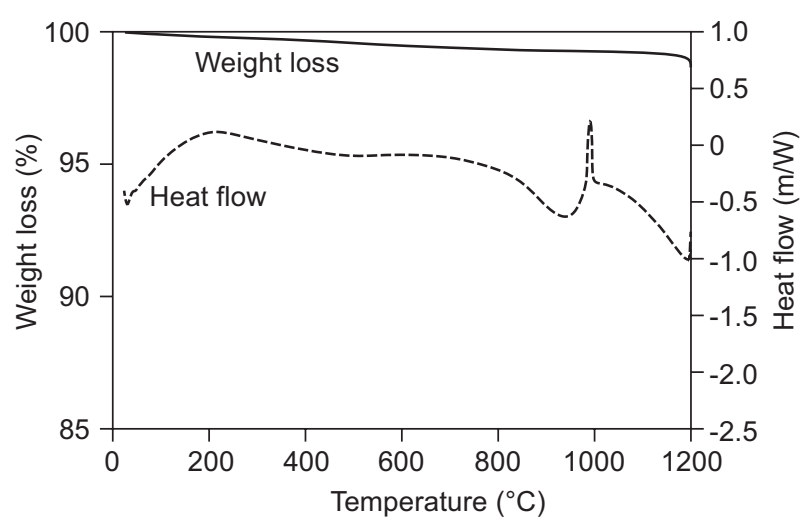

c) $\left(\mathrm{K}_{\mathrm{I}}+\mathrm{Fe}\right)_{\mathrm{ca}}$

Figure 3. Weight loss and heat flow curves for a) $\mathrm{K}_{\mathrm{I}}$, b) $\left(\mathrm{K}_{\mathrm{I}}+\right.$ $+\mathrm{Fe})_{\text {no ca }}$ and c) $\left(\mathrm{K}_{\mathrm{I}}+\mathrm{Fe}\right)_{\mathrm{ca}}$. 


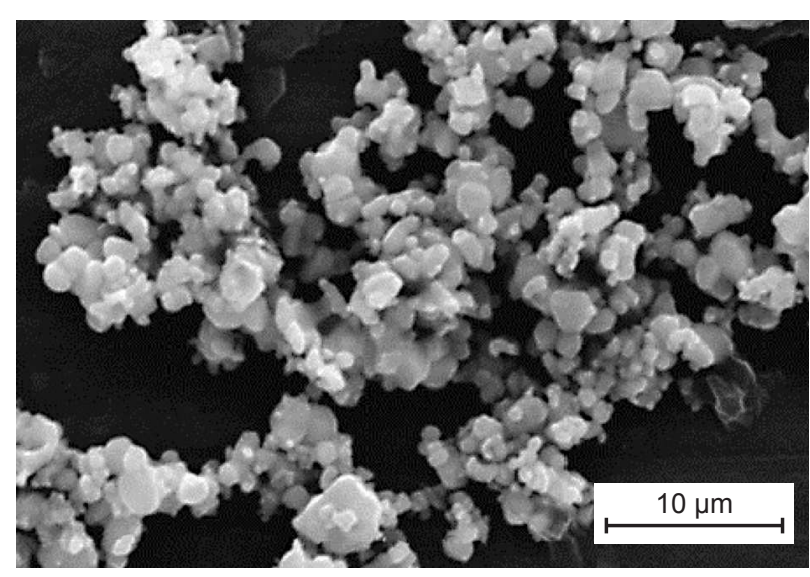

a) $\mathrm{Fe}_{2} \mathrm{O}_{3}$

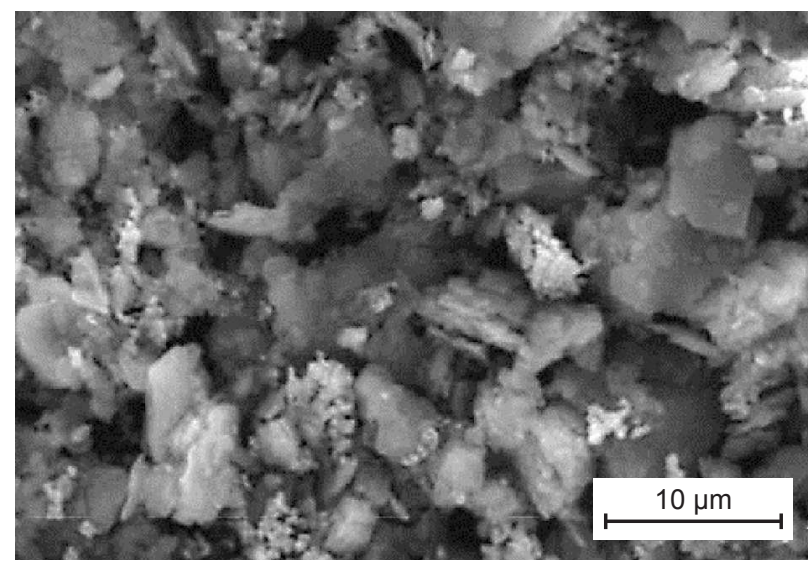

c) $\left(\mathrm{K}_{\mathrm{I}}+\mathrm{Fe}\right)_{\mathrm{ca}}$

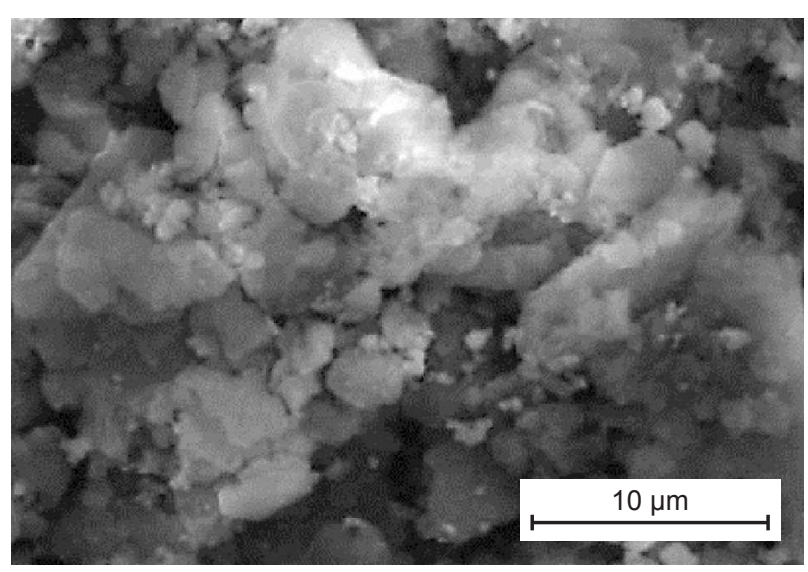

b) $\left(\mathrm{K}_{\mathrm{I}}+\mathrm{Fe}\right)_{\text {no ca }}$

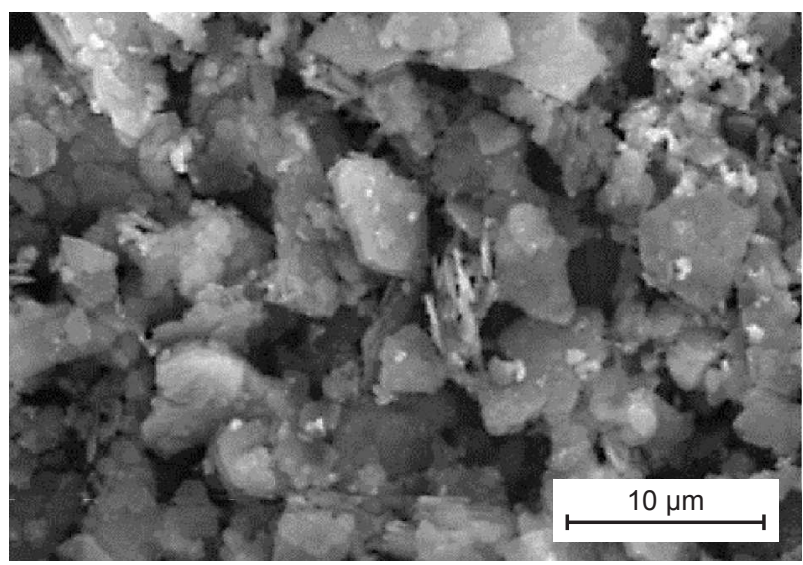

d) $\left(\mathrm{M}_{\mathrm{I}}+\mathrm{Fe}\right)$

Figure 4. SEM micrographs $\mathrm{Fe}_{2} \mathrm{O}_{3}(\mathrm{a}),\left(\mathrm{K}_{\mathrm{I}}+\mathrm{Fe}\right)_{\text {no ca }}(\mathrm{b}),\left(\mathrm{K}_{\mathrm{I}}+\mathrm{Fe}\right)_{\mathrm{ca}}(\mathrm{c})$ and $\left(\mathrm{M}_{\mathrm{I}}+\mathrm{Fe}\right)(\mathrm{d})$ of various precursors.

Consolidated material feasibility

The raw materials precursors were used to synthesize consolidated material from a mixture of potassium silicate and potassium hydroxide. The different samples were placed in an oven at $70^{\circ} \mathrm{C}$ for $2 \mathrm{~h}$ in a closed mold. To learn more about the geopolymerization reaction, volume shrinkage values are reported in Figure 5 that depend on the $\mathrm{Si} / \mathrm{K}$ molar ratio of the sample. The data show two families of materials, one with a $\mathrm{Si} / \mathrm{K}$ ratio greater than 0.99 and one with a $\mathrm{Si} / \mathrm{K}$ ratio less than 0.99 . The use of untreated kaolin provides materials with a drawal $<0.99$, regardless of the value of the $\mathrm{Si} / \mathrm{K}$ ratio. These cannot be considered geopolymer samples [20]. The use of calcined kaolin $\left(\mathrm{M}_{\mathrm{I}}\right)$ produces two types of materials, one with a shrinkage of 1 and the other with a shrinkage of less than 0.99 . The difference is due to the $\mathrm{KOH}$ content. A very large amount of $\mathrm{KOH}$ in the alkaline solution has the effect of bringing the different species together without a geopolymerization reaction, in agreement with the work performed by Gao et al. [21]. The addition of iron oxide $\left(\mathrm{M}_{\mathrm{I}}+\mathrm{Fe}\right)$ creates a material with a shrinkage of less than 0.99 . For low amounts of $\mathrm{KOH}$ in the alkaline solution, this phenomenon is minimized. It appears that the presence of iron oxide acts as a dispersant that limits the coating effect. These data are explained in further detail in the following sections.

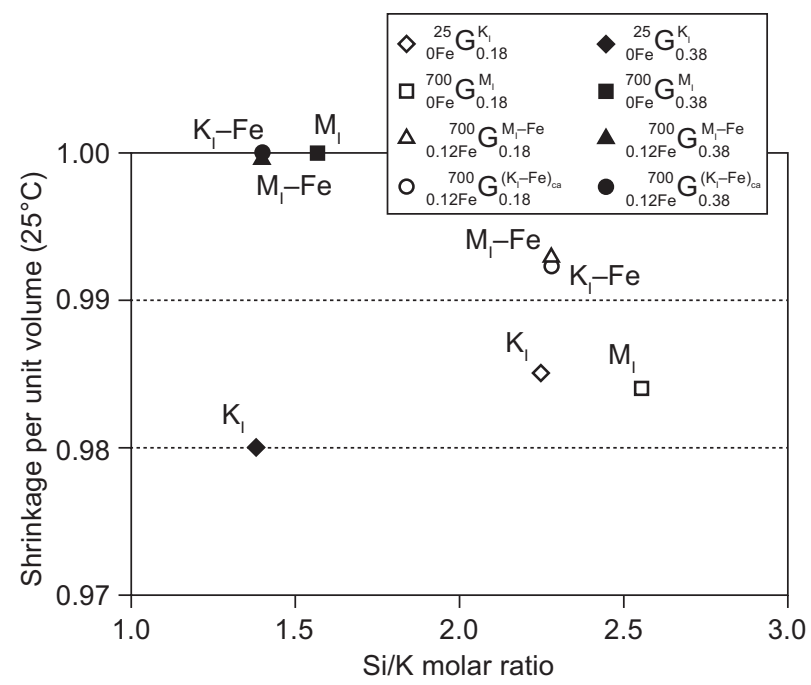

Figure 5. Shrinkage for different samples versus the $\mathrm{Si} / \mathrm{K}$ molar ratio. 


\section{Consolidated materials}

The different samples were characterized during consolidation by IR spectroscopy and, after 7 days, by XRD, SEM and TGA/DTA.

Monitoring the progress of the geopolymerization reaction is performed using FTIR spectroscopy by following the displacement of the $\mathrm{Si}-\mathrm{OM}$ band versus time (Figure 6). For different consolidation reactions, this displacement reflects the formation of bonds characteristic of a specific type of network $[22,23]$. The spectrum of the composition ${ }_{0}^{25} \mathrm{G}_{0.18}^{\mathrm{K}_{1}}$ synthesized with a small amount of $\mathrm{KOH}$ exhibits a displacement of approximately $9 \mathrm{~cm}^{-1}$ versus a displacement of approximately $6 \mathrm{~cm}^{-1}$ for large amounts of $\mathrm{KOH}$. These two values are considered a low shift from the high initial wave number of $1003 \mathrm{~cm}^{-1}$. For the samples containing only metakaolin

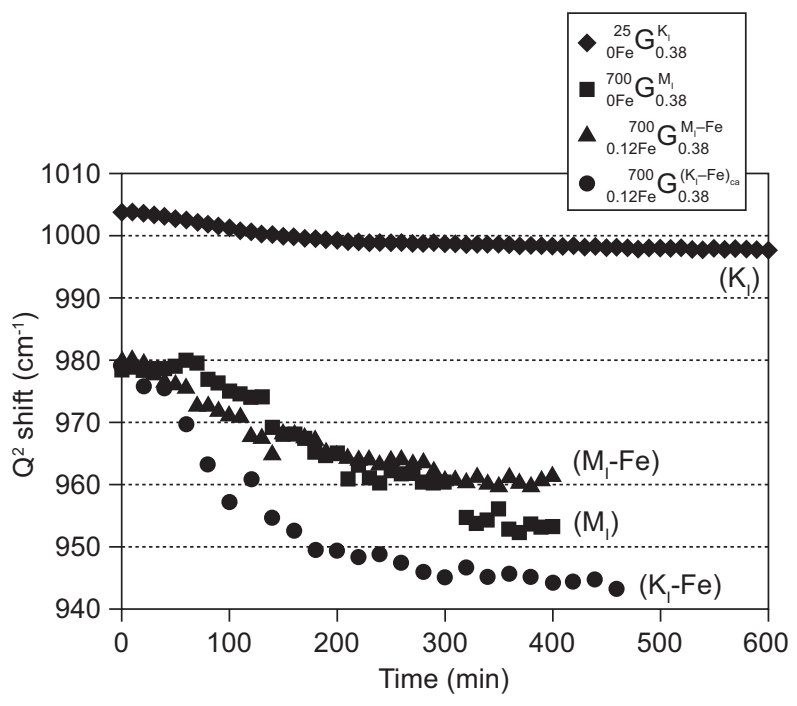

b)

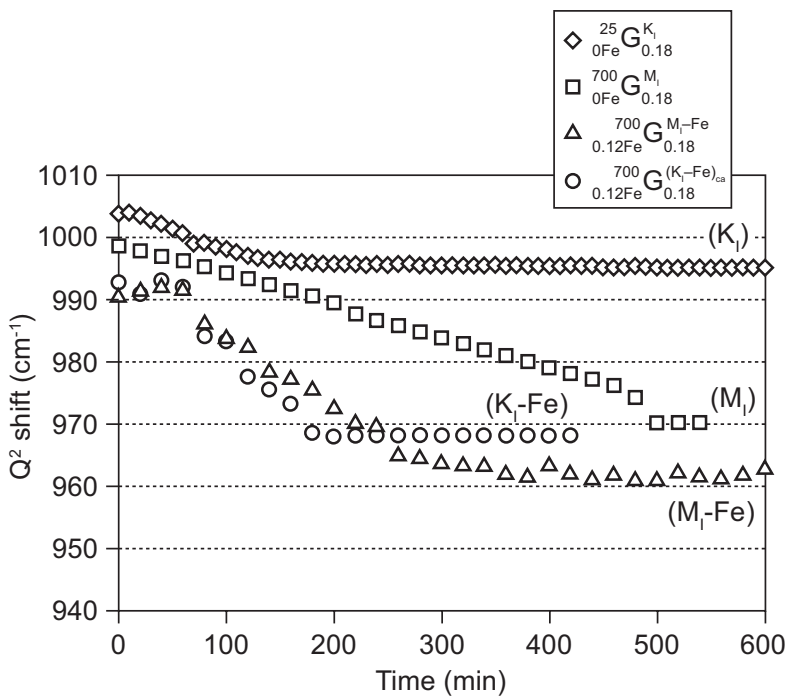

a)

Figure 6. Evolution of $\mathrm{Si}-\mathrm{O}-\mathrm{R}^{+}$band shift versus the time of reaction of polycondensation. $\left({ }_{0}^{700} \mathrm{G}_{0.18}^{\mathrm{M}_{\mathrm{l}}},{ }_{0}^{700} \mathrm{G}_{0.38}^{\mathrm{M}_{\mathrm{I}}}\right)$, the displacements are recorded $\left(28 \mathrm{~cm}^{-1}\right.$, $25 \mathrm{~cm}^{-1}$ ), and the initial values for the wave numbers are $998 \mathrm{~cm}^{-1}$ and $978 \mathrm{~cm}^{-1}$. The spectra of the compositions ${ }_{0.12 \mathrm{Fe}}^{700} \mathrm{G}_{0.18}^{\mathrm{M}_{\mathrm{K}}-\mathrm{Fe}},{ }_{0.12 \mathrm{Fe}}^{700} \mathrm{G}_{0.38}^{\mathrm{M}_{\mathrm{K}}-\mathrm{Fe}}$ in the presence of iron show displacements of 30 approximately $\mathrm{cm}^{-1}$ and $35 \mathrm{~cm}^{-1}$, respectively. For the composition ${ }_{0.12 \mathrm{Fe}} \mathrm{G}_{0.18}^{\left(\mathrm{K}_{1}-\mathrm{Fe}\right)_{\text {ca }}}$ and ${ }_{0.12 \mathrm{Fe}} \mathrm{G}_{0.38}^{\left(\mathrm{K}_{1} \mathrm{Fe}\right)_{\text {ca }}}$ the recorded displacements are 24 and $32 \mathrm{~cm}^{-1}$, respectively. When using kaolin $\left(\mathrm{K}_{\mathrm{I}}\right)$ in the presence of different quantities of $\mathrm{KOH}$ for the compositions $\left({ }_{0}^{25} \mathrm{G}_{0.18}^{\mathrm{K}_{1}},{ }_{0}^{25} \mathrm{G}_{0.38}^{\mathrm{K}_{1}}\right)$, the observed shift is very small. In this case, it is very difficult to form stable $\mathrm{Si}-\mathrm{O}-\mathrm{Al}$ bonds, and the observed difference in terms of the amount of $\mathrm{KOH}$ is insignificant because it lies within the uncertainty of the measurements. These results are consistent with the volume shrinkage, which shows that the samples are only consolidated and are not geopolymeric materials. The compositions $\left({ }_{0}^{700} \mathrm{G}_{0.18}^{\mathrm{M}_{1}}\right.$, ${ }_{0}^{700} \mathrm{G}_{0.38}^{\mathrm{M}_{1}}$ ) show a shift from an initial displacement, depending on the alkaline solution. When potassium is added, the number of non-bridging oxygen bonds increases the effect of reducing the initial value of the $\mathrm{Si}-\mathrm{OM}$ band. In the presence of high quantities of $\mathrm{KOH}$, the predominant silicate species are different. Indeed, for large amounts of $\mathrm{KOH}$, there is a monomer depolymerization for $\mathrm{Q}^{0}$ [24]. The decrease in the shift is important and proves that a polymerization reaction has taken place. The addition of iron to the mixtures ${ }_{0.12 \mathrm{Fe}} \mathrm{G}_{0.18}^{\mathrm{M}_{\mathrm{K}} \text {-Fe }},{ }_{0.12 \mathrm{Fe}} \mathrm{G}_{0.38}^{\mathrm{M}_{\mathrm{K}} \text {-Fe }}$ provides some information on the origin of this decreasing rate, which also depends on the initial amount of $\mathrm{KOH}$ in the solution and a similar shift ( 30 and $36 \mathrm{~cm}^{-1}$, respectively). For samples containing $\left(\mathrm{K}_{\mathrm{I}}+\mathrm{Fe}\right)_{\mathrm{ca}}$, the same phenomena are observed. It appears that when the calcination of kaolin occurs in the presence of $\mathrm{Fe}_{2} \mathrm{O}_{3}$, the $\mathrm{Si}-\mathrm{O}-\mathrm{Al}$ or $\mathrm{Si}-\mathrm{O}-\mathrm{K}$ bonds form faster for the corresponding geopolymer without iron oxide. In this case, a geopolymer network forms, and the iron oxide particles are dispersed. For the three groups of samples investigated here, it seems that there are polycondensation reactions due to this shift that are consistent with the dimensional changes that were observed previously.

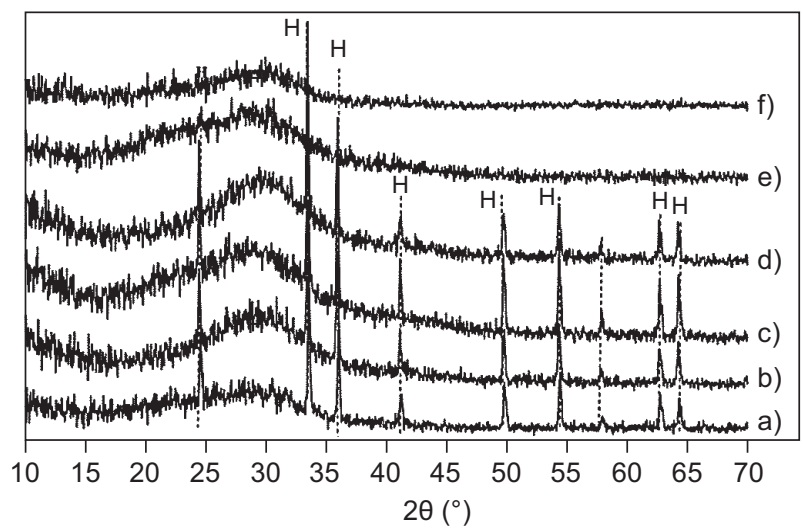

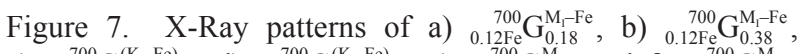
c) ${ }_{0.12 \mathrm{Fe}} \mathrm{G}_{0.18}^{\left(\mathrm{K}_{1}-\mathrm{Fe}\right)_{\text {ca }}}$, d) ${ }_{0.12 \mathrm{Fe}}^{700} \mathrm{G}_{0.38}^{\left(\mathrm{K}_{1}-\mathrm{Fe}\right)_{\text {ca }}}$, e) ${ }_{0.12 \mathrm{Fe}} \mathrm{G}_{0.18}^{\mathrm{M}_{1}}$ and $\mathrm{f}{ }_{0.12 \mathrm{Fe}} \mathrm{G}_{0.38}^{\mathrm{M}_{1}}$, consolidated materials (JCPDS Files: hematite (04-008-7624)). 
The role of hematite in aluminosilicate gels based on metakaolin

The diffractograms of these samples (Figure 7) are characteristic of an amorphous dome located at $30^{\circ}$. However, a broad peak near $28^{\circ}(2 \theta)$ was also formed and is similar to what has been observed in aluminosilicate systems [25]. The consolidated samples $\left({ }_{0 \mathrm{Fe}}^{25} \mathrm{G}_{0.18}^{\mathrm{K}_{1}},{ }_{0 \mathrm{Fe}}^{25} \mathrm{G}_{0.18}^{\mathrm{K}_{1}}\right)$ contain a lot of water and have not been studied using X-ray diffraction. The formation of the amorphous dome is a characteristic feature of geopolymerization. However, in the presence of a larger amount of $\mathrm{KOH}$, the intensity of the amorphous dome increases. This result may be due to additional phase dissolution in the presence of high concentrations of $\mathrm{KOH}$ [26]

The SEM photos representative of the microstructure for the different synthesized samples are shown in Figure 8 . The observed microstructures are characteristic of material consolidation in all of the compositions [27]. The noticeable presence of iron on the different samples suggests that the corresponding oxide did not react during the consolidation process. A comparison of a sample of ${ }_{0.12 \mathrm{Fe}}^{700} \mathrm{G}_{0.18}^{\mathrm{M}_{\mathrm{K}} \text {-Fe }}$ and the geopolymer synthesized based clay Medenine $\left({ }_{0.18}^{700} \mathrm{G}_{0.5}^{\mathrm{M}}\right)$ shows no difference in the microstructure. However, the detected particles highlight the unresponsiveness of iron during these consolidation stages at the microscopic level.

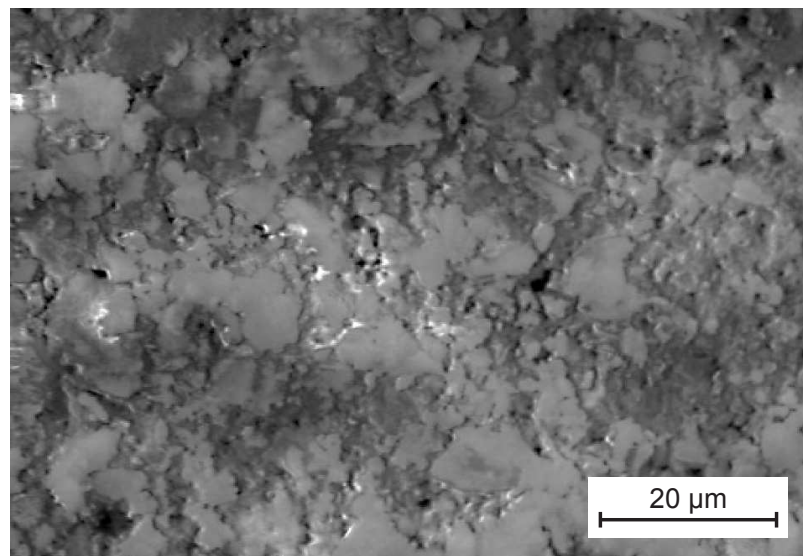

a) ${ }_{0.18}^{700} \mathrm{G}_{0.5}^{\mathrm{M}_{1}-0.12 \mathrm{Fe}}$

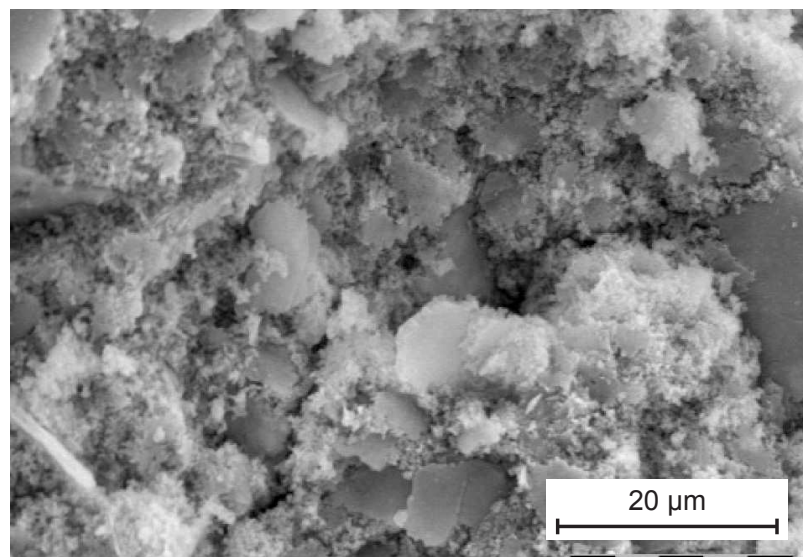

c) ${ }_{0.38}^{700} \mathrm{G}_{0.5}^{\left(\mathrm{K}_{1}-0.12 \mathrm{Fe}\right)_{\text {ca }}}$
The main results based on these various formulations evidenced that the hematite addition don't modify the nature of the final network due to polycondensation reaction. In effect, these compounds do not contain the iron as network formatter as evidence by Kriven et al [28]. Indeed, in this work, the iron element was introduced in the form of magnetite. Nevertheless, the modification of the slope, deduced from IR results, can be correlated to the coating of iron oxide particles with alkaline solution. In addition, the microstructure of different samples highlights the non-reactivity of iron during these stages of consolidation. In general, the contribution of iron oxide seems to be inactive in these conditions.

The thermograms of the various compositions are shown in Figure 9. The thermograms of the kaolin based samples ${ }_{0 \mathrm{Fe}}^{25} \mathrm{G}_{0.18}^{\mathrm{K}_{1}},{ }_{0 \mathrm{Fe}}^{25} \mathrm{G}_{0.38}^{\mathrm{K}_{1}}$ exhibit mass losses (36\% and $34 \%$ ) associated with the loss of the water in the mixture and the transformation of kaolin into metakaolin dehydroxylation at $\mathrm{T}=500^{\circ} \mathrm{C}$. The amount of $\mathrm{KOH}$ introduced does not affect these curves.

For the other six samples containing metakaolin, the mass loss is between 10 and $15 \%$, suggesting that these compounds are preferred for polycondensation reactions that may lead to geopolymerization [29].

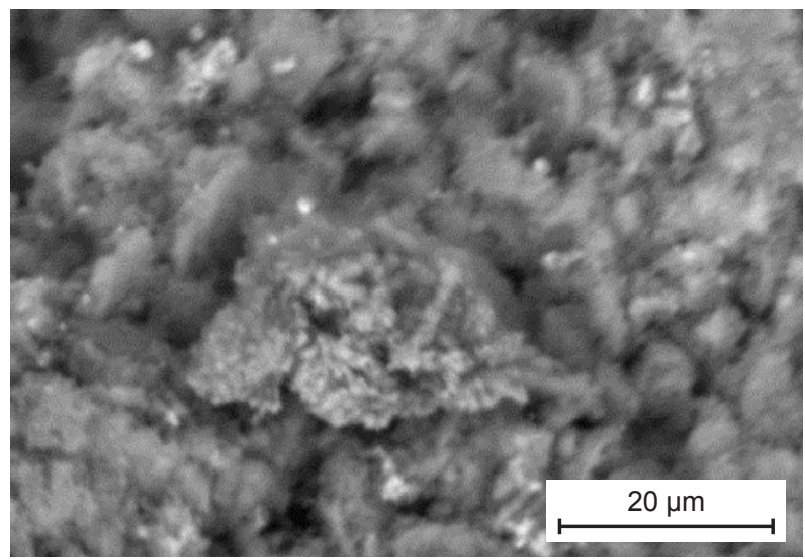

b) ${ }_{0.18}^{700} \mathrm{G}_{0.5}^{\left(\mathrm{K}_{1}-0.12 \mathrm{Fe}\right){ }_{\mathrm{ca}}}$

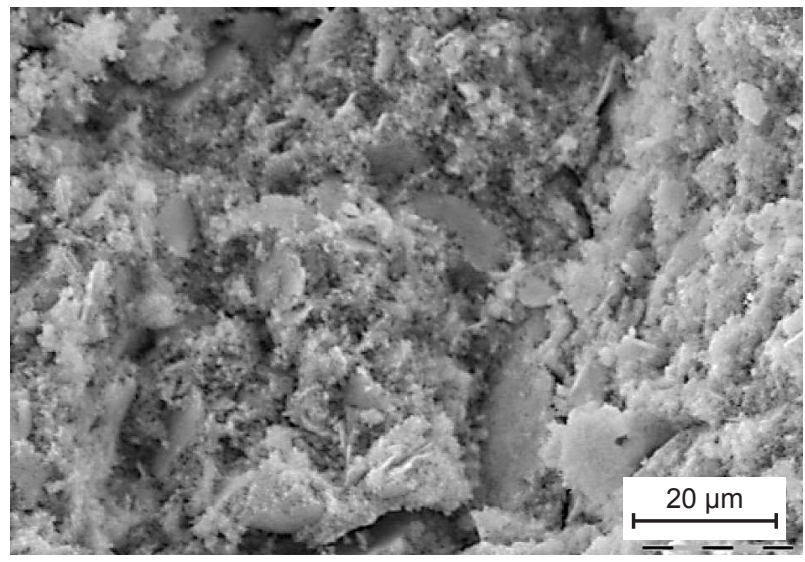

d) ${ }_{0.38}^{700} \mathrm{G}_{0.5}^{\mathrm{M}_{1}-0.12 \mathrm{Fe}}$

Figure 8. MEB photos of consolidated materials. 


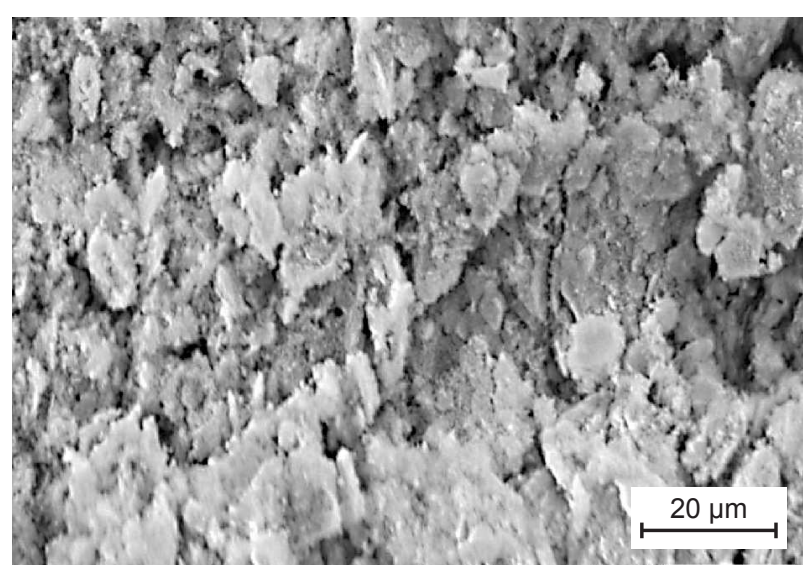

e) ${ }_{0.18}^{700} \mathrm{G}_{0.5}^{\mathrm{M}-0 \mathrm{Fe}}$

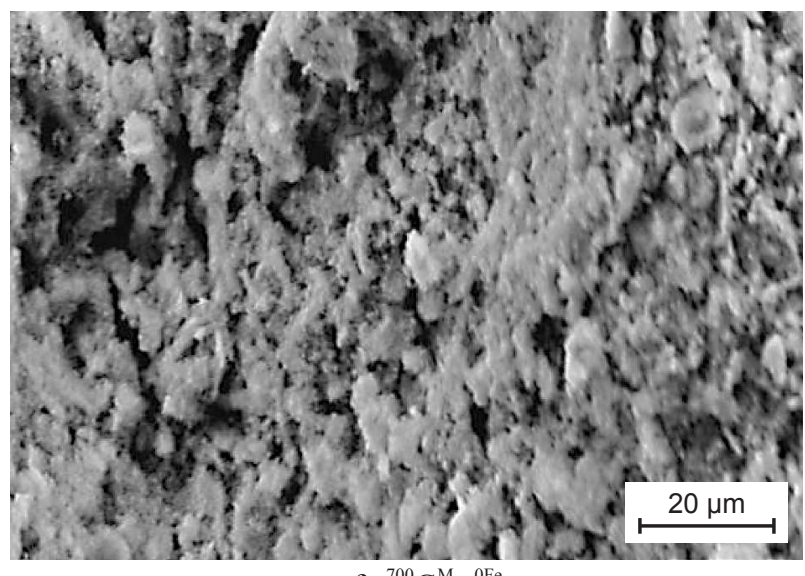

f) ${ }_{0.38}^{700} \mathrm{G}_{0.5}^{\mathrm{M}_{1}-\mathrm{OFe}}$

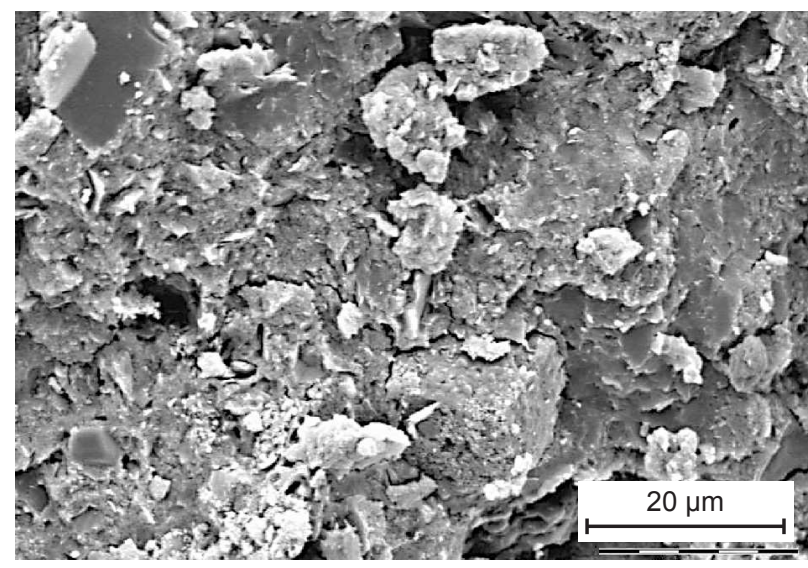

g) ${ }_{0.18}^{700} \mathrm{G}_{0.5}^{\mathrm{M}}$

Figure 8. MEB photos of consolidated materials.

No matter which sample is examined, the first endothermic peak has at least two contributors, one at $80^{\circ} \mathrm{C}$ and the other at $180^{\circ} \mathrm{C}$. This result suggests that the water is physisorbed and eliminated during the heat treatment. The endothermic peak at $450^{\circ} \mathrm{C}$ may be attributed to an aluminosilicate compound that forms via different reactions in a basic environment [30]. Indeed, phase-type zeolites may be formed. In this case, the concentrations of $[\mathrm{Si}]$ and $[\mathrm{K}]$ are, respectively, 22 and $9 \mathrm{~g} \mathrm{~mol}^{-1}$ for the sample of ${ }_{0.12 \mathrm{Fe}}^{700} \mathrm{G}_{0.18}^{\mathrm{M}_{\mathrm{K}}-\mathrm{Fe}}$ in the zeolite formation zone, as determined by Prud'homme et al. [31]. However, in the presence of a large amount of $\mathrm{KOH}$, the formation of this compound is less common. We also consider the presence of iron, which may change the formation of these phases by changing the reaction medium. It has been proven that there is no interaction between the iron oxide and the potassium hydroxide. The silicate species containing $\mathrm{KOH}$ remains around the particles of hematite [8].

Geopolymer with Fe admixture show low values of mechanical properties (Table 1) because of the friable character of these materials display different networks aluminosilcates in agreement with the results of Cheol et al., 2012 [6]. They have showmen that the addition of $\mathrm{Fe}_{2} \mathrm{O}_{3}$ in geopolymer systems decreased the mechanical properties. Indeed, as example, the addition of $5 \%$ of $\mathrm{Fe}_{2} \mathrm{O}_{3}$ leads to a decreasing from 70 to $32 \mathrm{MPa}$.

\section{DISCUSSIONS}

The materials obtained from polycondensation reaction were amorphous. Their formation could be described by the silicate solutions containing $\mathrm{KOH}$ remains around the particle of hematite and interacting with metakaolin evidencing the presence of different networks. So to investigate the various networks formed, it is important to study the reactivity of the mixture determined by FTIR measurements and the temperature stability of the samples by thermal analysis.

The evolution of the band shift of the $\mathrm{Si}-\mathrm{OM}$ depending on the slope reduced the amount of water contained in the solution $\mathrm{SiK}$ [32] for all samples is reported in Figure 10. From these data, it is possible to define the existence of various types of materials depending on their chemical composition and their rate of silicon by reactive surface as established by the work of Gouny [31]. Indeed, for a value of between 0 and $22 \mathrm{~cm}^{-1}$, it had preferentially polycondensation reactions between siliceous species leading to gel formation, whereas for above $22 \mathrm{~cm}^{-1}$ value, the formation of different aluminosilicate networks is preponderant. From these data, the samples $\left(\mathrm{K}_{\mathrm{I}}\right)$, present low values of displacement, are composed of at least a binder phase that maintains a partial cohesion. In this case, the formed materials are simply agglomerated with alkaline solution and drying. Conversely, the other samples $\left(\mathrm{M}_{\mathrm{I}}, \mathrm{M}_{\mathrm{I}}-\mathrm{Fe}\right.$, $\mathrm{K}_{\mathrm{I}}-\mathrm{Fe}$ ) with different rate of $\mathrm{KOH}$, have respectively values of displacement $\left(28,35,32 \mathrm{~cm}^{-1}: \mathrm{Si} / \mathrm{K}=0.2\right)$. Their slopes values are low not exceeding $-0.1 \mathrm{~cm}^{-1} / \mathrm{s}$. Consequently, there is formation of different networks consist in geopolymer binder phase type, aluminosilicate phase and/or a platelet adhesion unaltered by excess solution [33].

The evolution of the band shift of the Si-OM according to the water mass loss (Table 2) of the different samples in $\left[200-500^{\circ} \mathrm{C}\right]$ is shown in Figure 11 . 
The role of hematite in aluminosilicate gels based on metakaolin

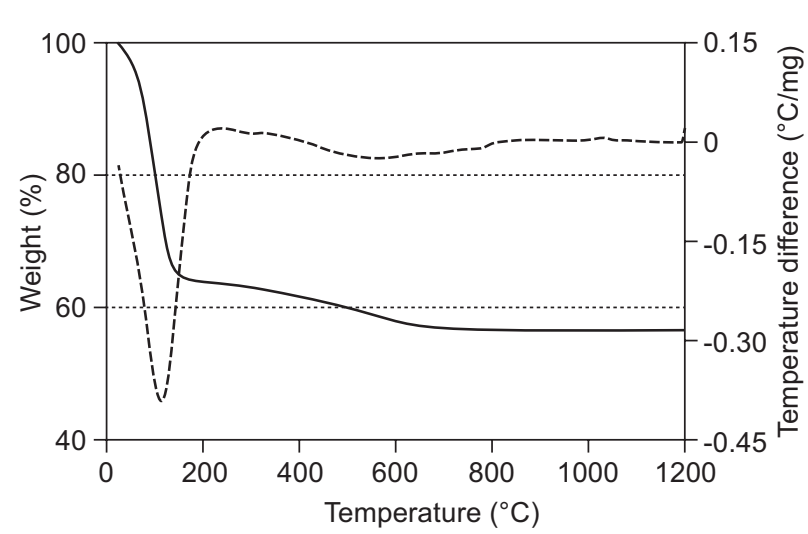

a) ${ }_{0 \mathrm{Fe}}^{25} \mathrm{G}_{0.18}^{\mathrm{K}_{1}}$

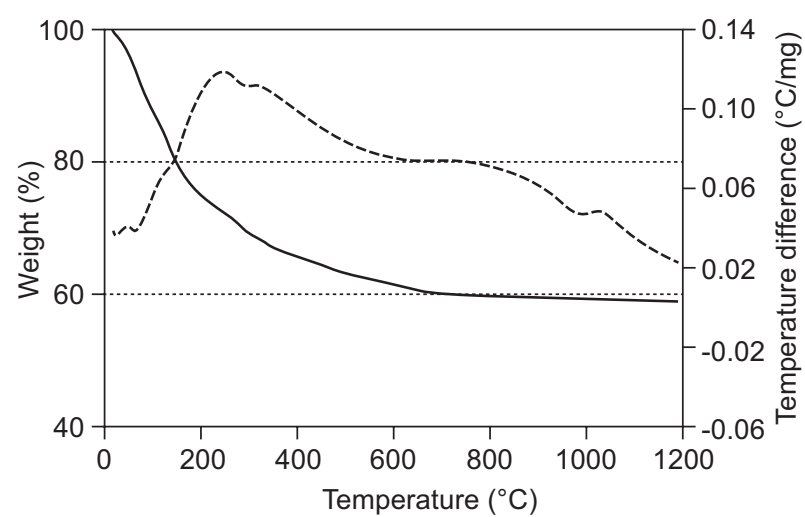

c) ${ }_{0.12 \mathrm{Fe}} \mathrm{G}_{0.18}^{\left(\mathrm{K}_{1}-\mathrm{F}\right)_{\mathrm{cas}}}$

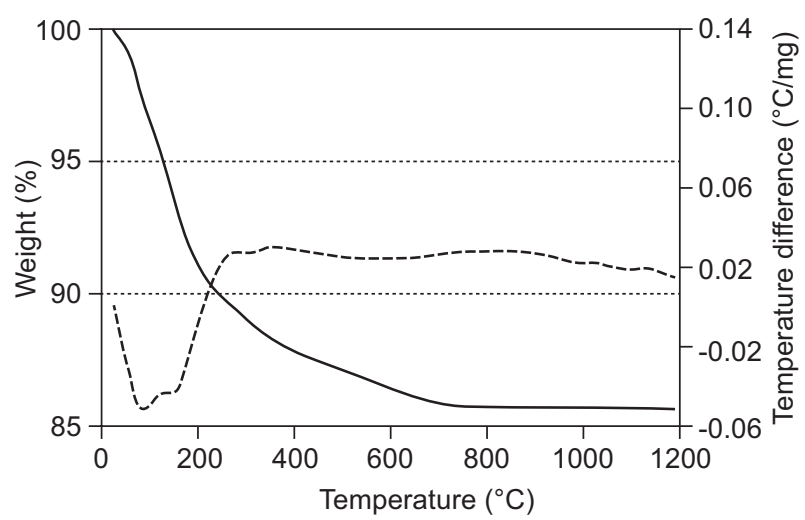

e) ${ }_{0 \mathrm{Fe}}^{700} \mathrm{G}_{0.18}^{\mathrm{M}_{1}}$

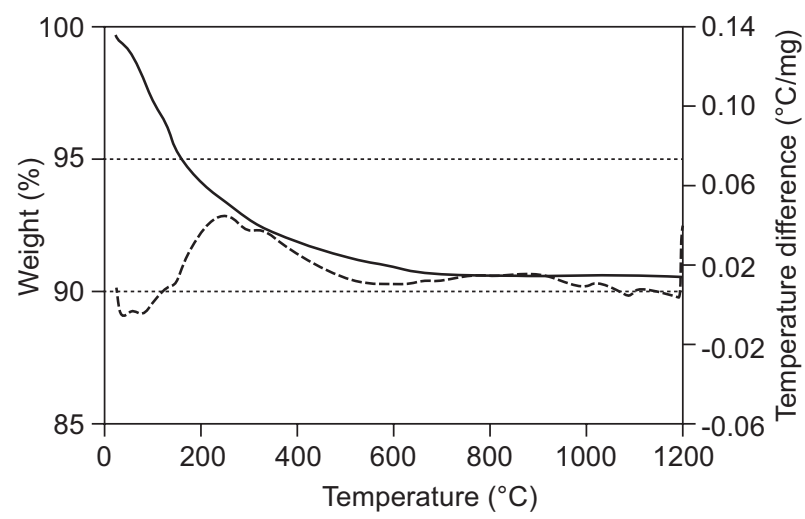

g) ${ }_{0.12 \mathrm{Fe}}^{700} \mathrm{G}_{0.18}^{\mathrm{M}_{1}-\mathrm{Fe}}$

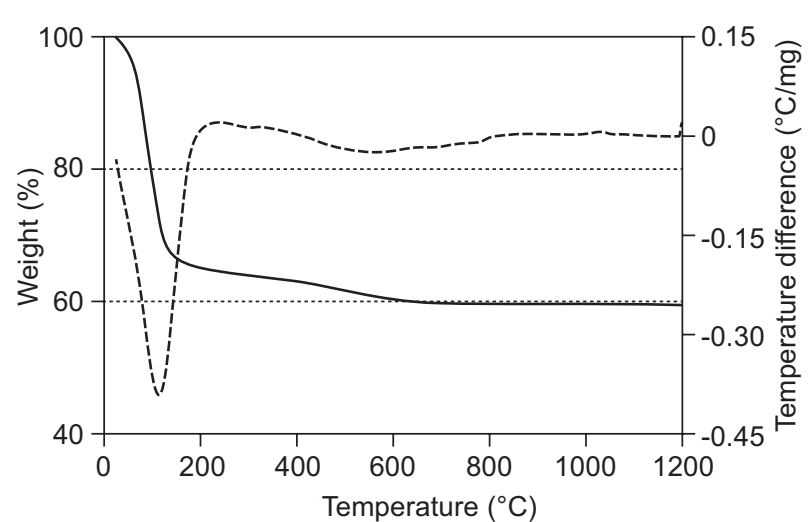

b) ${ }_{0 \mathrm{Fe}}{ }^{25} \mathrm{G}_{0.38}^{\mathrm{K}_{1}}$

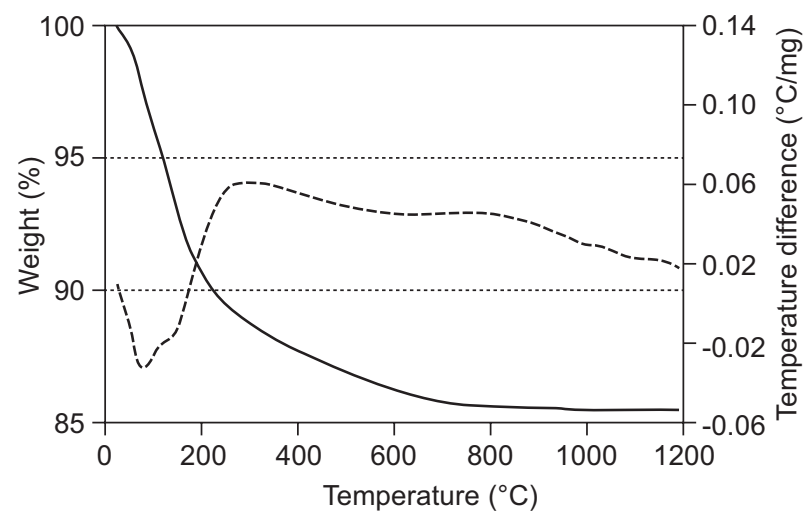

d) ${ }_{0.12 \mathrm{Fe}}^{700} \mathrm{G}_{0.38}^{\left(\mathrm{K}_{1}-\mathrm{F}\right)_{\text {cas }}}$

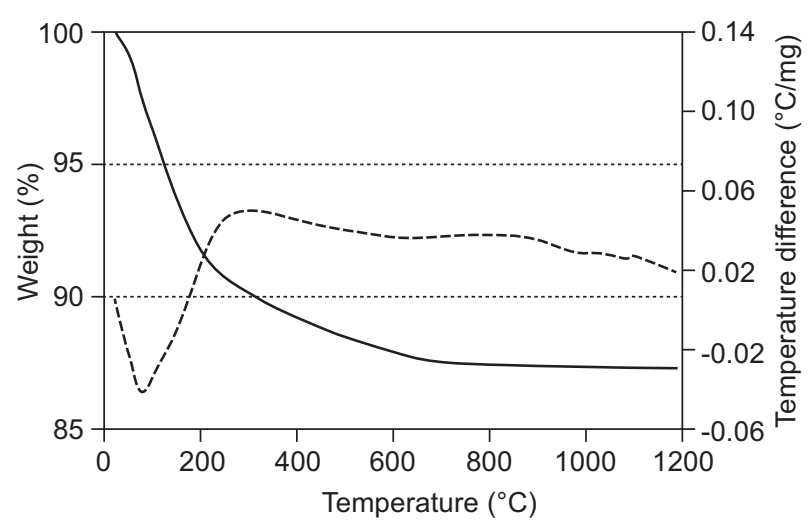

f) ${ }_{0 \mathrm{Fe}}^{700} \mathrm{G}_{0.38}^{\mathrm{M}_{1}}$

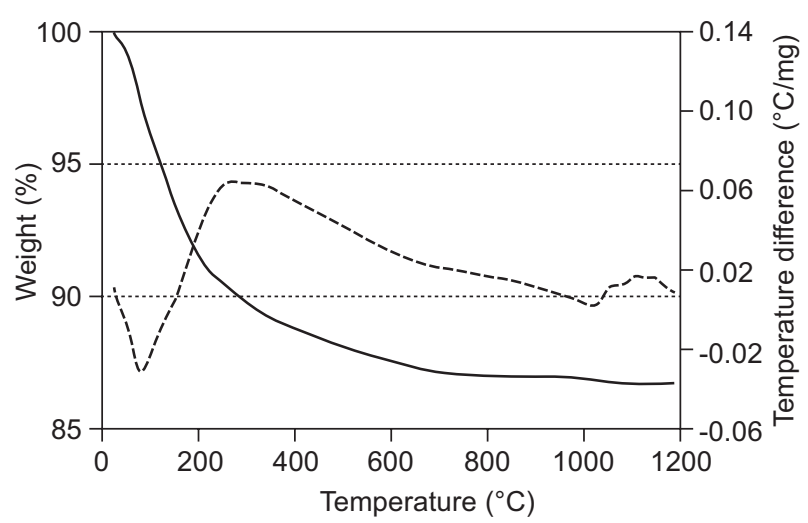

h) ${ }_{0.12 \mathrm{Fe}}^{700} \mathrm{G}_{0.38}^{\mathrm{M}_{1}-\mathrm{Fe}}$

Figure 9. Thermal curves of consolidated materials. 
Table 2. Moles number determined by thermal analysis of samples.

\begin{tabular}{|c|c|c|c|}
\hline \multirow{2}{*}{ Samples } & \multicolumn{3}{|c|}{ Number of moles of water $\left(10^{-5}\right)$} \\
\hline & {$\left[25-200^{\circ} \mathrm{C}\right]$} & {$\left[200-500^{\circ} \mathrm{C}\right]$} & {$\left[<500^{\circ} \mathrm{C}\right]$} \\
\hline $\begin{array}{l}700 \mathrm{G}_{0.18}^{\mathrm{M}_{1}-\mathrm{Fe}} \\
0.12 \mathrm{Fe}\end{array}$ & 4.19 & 1.51 & 1.35 \\
\hline${ }_{0.12 \mathrm{Fe}} \mathrm{G}_{0.38}^{\mathrm{M}_{1}-\mathrm{Fe}}$ & 9.22 & 1.26 & 2.44 \\
\hline${ }_{0.12 \mathrm{Fe}}^{700} \mathrm{G}_{0.18}^{\left(\mathrm{K}_{1}-\mathrm{Fe}\right)_{\mathrm{ca}}}$ & 6.35 & 2.83 & 1.03 \\
\hline $\begin{array}{l}700 \\
0.12 \mathrm{Fe} \\
\mathrm{G}_{0.38}^{\left(\mathrm{K}_{1}-\mathrm{Fe}\right)_{\text {са }}}\end{array}$ & 10.15 & 1.69 & 2.07 \\
\hline${ }_{0 \mathrm{Fe}}^{700} \mathrm{G}_{0.18}^{\mathrm{M}_{\mathrm{l}}}$ & 13.02 & 4.55 & 3.01 \\
\hline${ }_{0 \mathrm{Fe}} \mathrm{G}_{0.38}^{\mathrm{M}_{1}}$ & 9.14 & 4.57 & 0.15 \\
\hline${ }_{0 \mathrm{Fe}}^{25} \mathrm{G}_{0.18}^{\mathrm{K}_{1}}$ & 6.55 & 0.428 & - \\
\hline${ }_{0 \mathrm{Fe}}^{25} \mathrm{G}_{0.38}^{\mathrm{K}_{1}}$ & 5.70 & 1.026 & - \\
\hline
\end{tabular}

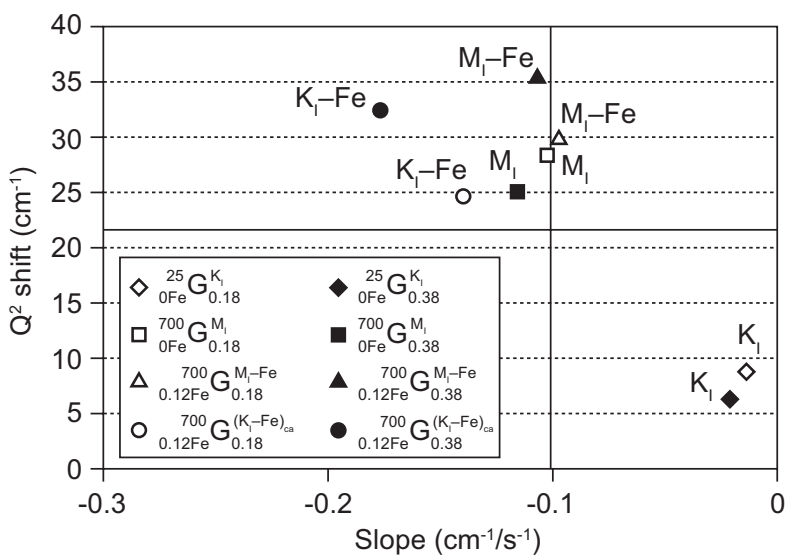

Figure 10. Evolution of shift versus slope for various samples.

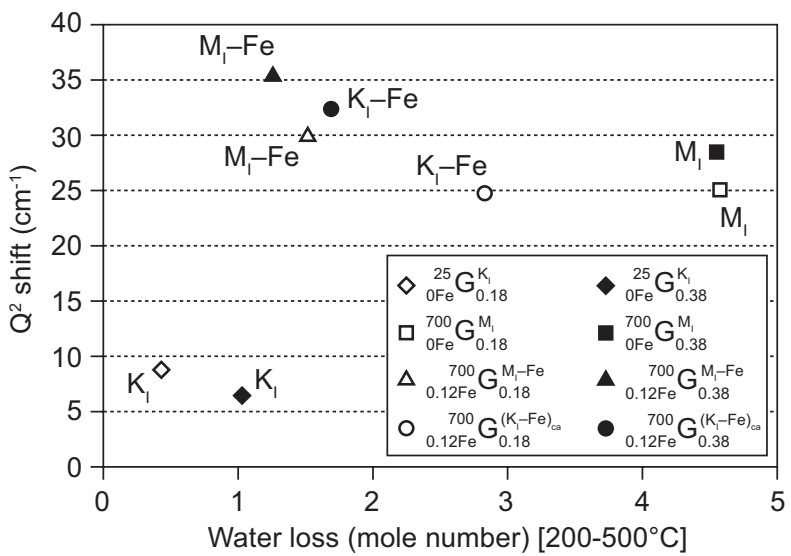

Figure 11. Evolution of shift versus water loss (mole number) for various samples.

The compositions of $\mathrm{K}_{\mathrm{I}}$ in the presence of different levels of $\mathrm{KOH}\left({ }_{0 \mathrm{Fe}}^{25} \mathrm{G}_{0.18}^{\mathrm{K}_{1}},{ }_{0 \mathrm{Fe}} \mathrm{G}_{0.38}^{\mathrm{K}_{1}}\right)$ show low weight loss justifying their brittle character. For compositions containing iron oxide, such as $\left({ }_{0.12 \mathrm{Fe}} \mathrm{G}_{0.18}^{\mathrm{M}_{\mathrm{K}}-\mathrm{Fe}},{ }_{0.12 \mathrm{Fe}} \mathrm{G}_{0.38}^{\mathrm{M}_{\mathrm{K}} \mathrm{Fe}}\right.$, $\left.{ }_{0.12 \mathrm{Fe}} \mathrm{G}_{0.18}^{\left(\mathrm{K}_{1}-\mathrm{Fe}\right)_{\mathrm{ca}}},{ }_{0.12}^{700} \mathrm{G}_{0.38}^{\left(\mathrm{K}_{1}-\mathrm{Fe}\right)_{\text {ca }}}\right)$, the calculated weight loss increases as the FTIR shift decreases. With the exception of the $\mathrm{M}_{\mathrm{I}}$ and $\mathrm{K}_{\mathrm{I}}$ based samples, only a slight decrease in the mass loss is recorded with increasing displacement.
It is noted that for all compositions containing iron oxide, the amount of water increases as the displacement decreases.

These results agree with the formation of geopolymer consolidated materials. In effect, the compounds containing $\left(\mathrm{K}_{\mathrm{I}}-\mathrm{Fe}\right),\left(\mathrm{M}_{\mathrm{I}}-\mathrm{Fe}\right)$ and $\mathrm{M}_{\mathrm{I}}$ have molar compositions corresponding to the geopolymers or stratified compounds identified by Gao et al. in ternary $\mathrm{Si}-\mathrm{Al}-\mathrm{K}-\mathrm{O}$ [21].

Finally, the data obtained on the reactivity of the raw materials, the behavior of the reaction mixture, the final structure of materials, allow the proposal of the model of reactivity during synthesis presented in Figure 12. The potassium silicate solution was placed in the presence of different sources of aluminosilicates that causes formation of different networks: (i) metakaolin $\left(\mathrm{M}_{\mathrm{I}}\right)$ leads to the formation of a geopolymer gel phase and a rich siliceous species (ii) kaolin $\left(\mathrm{K}_{\mathrm{I}}\right)$ is simply agglomerated with the alkaline solution by drying (iii) mixtures of $\left(\mathrm{Fe}+\mathrm{K}_{\mathrm{I}}\right)_{\mathrm{ca}}$ or $\left(\mathrm{M}_{\mathrm{I}}+\mathrm{Fe}\right)$ leads to the formation of a compound consisting of a solid network geopolymer in interaction phase with an aluminosilicate coating solution.

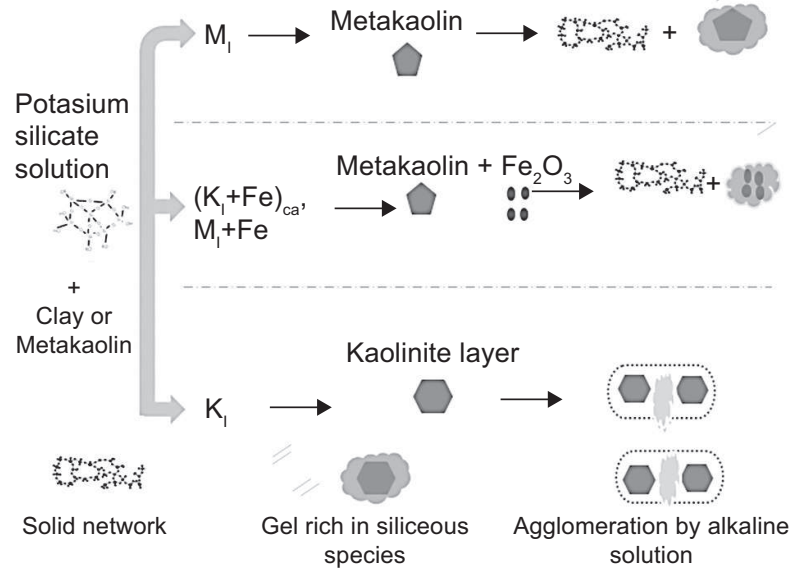

Figure 12. Schema of the various steps leading to $\mathrm{K}_{\mathrm{I}}, \mathrm{M}_{\mathrm{I}}$, $\left(\mathrm{K}_{\mathrm{I}}+\mathrm{Fe}\right)_{\mathrm{ca}}$ and $\left(\mathrm{M}_{\mathrm{I}}+\mathrm{Fe}\right)$ settings materials.

\section{CONCLUSIONS}

In this work, we have discussed consolidated materials obtained from kaolin or metakaolin mixed with iron oxide. These materials were characterized in-situ and after consolidation using different characterization methods.

The analysis of the precursor materials reveals that regardless of the calcined precursors utilized in this study, they are characterized by the presence of hematite and an amorphous phase derived from the clay components. 
The existence of an amorphous dome on the diffractograms of the consolidated materials and the shift of the $\mathrm{Si}-\mathrm{O}-\mathrm{R}^{+}$band are characteristic of a polycondensation reaction. It appears that when the kaolin is calcined and iron oxide is present, $\mathrm{Si}-\mathrm{O}-\mathrm{Al}$ or $\mathrm{Si}-\mathrm{O}-\mathrm{K}$ bonds form faster in the consolidated material than without iron oxide. The presence of a higher concentration of $\mathrm{KOH}$ may influence the formation of consolidated materials.

Representative characterization by electron microscopy of the microstructure of different samples highlights the non-reactivity of iron during these stages of consolidation.

The role of iron in geopolymerization has not been adequately explored. The presence of iron oxide modifies the formation of geopolymer compounds leading to the formation of consolidated materials. In fact, these materials contain different specific networks with geopolymer binder. The interactions between various networks inhibit mechanical properties.

\section{REFERENCES}

1. Chakchouk A., Samet B., Mnif T: Appl .Clay. Sci. 33, 9 (2006).

2. Krichen M., Bonnet J. P., Bouaziz J., Baklouti S: Sci. Ind. 74, 5 (2009).

3. Essaidi N., Samet B., Baklouti S., Rossignol S: Appl. Clay .Sci. (2013) in press.

4. Bell J.L., Kriven W.M: Ceram. En. Sci. Proc. 30, 11 (2010).

5. Perera D.S., Cashion J.D., .Blackford M.G., Zhang Z., Vance E.R: J. Eu. Ceram. Soc. 27, 6 (2007).

6. Choi S., Lee W K: Mater. Res. 586, 3 (2012).

7. Ishikawa K., Yoshioka T., Sato T., Okuwaki A: Hydr. 45, 6 (1997).

8. Jordan N., Marmier N., Lomenech C., Griffaut E., Ehrhardt J. J: J. Col. Inter. Sci. 321, 5 (2007).

9. Pialy P.: Etude de quelques matériaux argileux du site de Lembo (Cameroun) : minéralogie, comportement au frittage et analyse des propriétés d'élasticité. Thèse à l'Université de Limoges. (2009)

10. Manoharan C., Sutharsan P., Dhanapandian S., Venkatachalapathy R: J. Mol. Struct. 1027, 4 (2012).

11. Soro N S : Influence des ions fer sur les transformations thermiques de la kaolinite, Thèse de l'Université de Limoges., (2003).

12. Essaidi N., Samet B., Baklouti S., Rossignol S: CeramicsSilikaty 57, 3, (2013).
13. Prud'homme E ., Michaud P ., Joussein E ., Peyratout C., Smith A., Arrii-Clacens S., Clacens J M ., S, Rossignol: J. Eur. Ceram. Soc. 30, 7 (2010).

14. Prud'homme E., Michaud P., Joussein E., Clacens J.M., Rossignol S.: J. N- Cry. Sol. 357, 8 (2011).

15. Golden D.C., Dixon J.B.: J. Amer. Chem. Soc. 49, 8 (1985).

16. Murat M., Ambroise J., Pera J. in: 87th Annual meeting of the American ceramic society, Cincinnati, Ohio; May 5-9, 1985.

17. Acebal S.G., Mijovilovich A., Rueda E. H., Aguirre M. E., Saragovi C.: Clay. Clay. Miner. 48, 10 (2000).

18. Autef A., Joussein E., Poulesquein A., Gasgnier G., Pronier S., Rossignol S.: Influence of metakaolin purities for the potassium geopolymer formulation: existence of several networks . Journal of Colloid and Interface Sciences. (2013)

19. Castellein O.: Influence de la vitesse $d u$ traitement thermique sur le comportement d'un kaolin : application au frittage rapide, Thèse de l'Université de Limoges $n^{\circ} 60$., (2000).

20. Kani E.N., Allahverdi A.: J. Mater. Sci. Eng. 8, 10 (2011).

21. Gao X.X., Autef A., Prud'homme E., Michaud P., Joussein E ., Rossignol S.: J. Sol-Gel Sc. Tec. 6, 9 (2013).

22. Ress C. A., Provis J. L., Luckey G. C., Van Deventer J.S.J.: Lang. 23, 9 (2007).

23. Ress C.A., Provis J.L., Luckey G.C., Van Deventer J.S.J.: Langmuir. 23, 6 (2007).

24. Prud'homme E., Autef A., Essaidi N., Michaud P., Samet B., Joussein E., Rossignol S.: App. Clay. Sci. 73, 2 (2012).

25. Davidovits J.: Journal Materials Educations 16, 91, (1994).

26. Duxson P., Provis J. L., Lukey. G.C., Mallicoat S.W., Kriven W.M., Van Deventer J.S.J.: Coll. Sur A: Phy. Eng. Asp. 269, 11 (2005).

27. Kong D. L.Y., Sanjayan J.G., Sagoe-Crentsil K.: Cem. Concr. Res. 37, 6 (2007).

28. Dileep S., Waltraud. M. in: Collection of papers presented at the $33^{\text {rd }}$ international Conference on advanced Ceramics and composites, January 18-23, 2009.

29. Duxon P., Lukeyand G. C., Van Deventer J.S.J.: J. Non Crys. Sol. 352, (2006).

30. Rahier H., Van Mele B., Wastiels J: J. Mater. Sci. 31, 5 (1996).

31. Prud'homme E., Michaud P., Joussein E., Rossignol S.: J. N. Crys. Sol. 358, 8 (2012).

32. Gouny F.: Nouveau système constructif multi matériaux bois/liant géopolymères/brique de terre crue: formulation, caractérisation et transfert d'échelle. Thèse à l'Université de Limoges, 2013.

33. Autef A.: Formulation géopolymère: influence des rapports molaires $\mathrm{Si} / \mathrm{K}$ et $\mathrm{Si} / \mathrm{Al}$ sur les réactions de polycondensation au sein de gels aluminosilicatés. Thèse de l'université de Limoges, 2013. 